\title{
Observations on Estrus as Monitored by Receptivity to Mating Activity and Pattern of Vaginal Exfoliates In Trypanosoma brucei - Infected WAD Goat does Synchronized with Estrumate ${ }^{\circledR}$
}

\author{
Observaciones sobre el Estro Monitorizado por la Receptividad a la Actividad \\ de Apareamiento y el Patrón de Exfoliación Vaginal en Cabras WAD \\ Infectadas por Trypanosoma brucei Sincronizadas con Estrumate ${ }^{\circledR}$
}

Olufisayo Oluwadamilare Leigh \& Oluremi Eric Fayemi

LEIGH, O. O. \& FAYEMI, O. E. Observations on estrus as monitored by receptivity to mating activity and pattern of vaginal exfoliates In Trypanosoma brucei - infected WAD goat does synchronized with Estrumate®. Int. J. Morphol., 29(3):762-768, 2011.

SUMMARY: The effects of experimental Trypanosoma brucei infection on receptivity to mating activity and pattern of vaginal exfoliates were monitored using twenty-one adult WAD goats which were synchronized with double injection, seven days apart of Estrumate ${ }^{\circledR}$. The twenty-one goats consisted of 3 bucks and 18 does. The does were randomly divided into control group 'A' having 10 does and test group 'B' with 8 does. The goats were fed with Elephant grass in the morning and commercial feed containing $15.23 \% \mathrm{CP}$ at the rate of $0.25 \mathrm{~kg} / \mathrm{head}$ in the afternoons. Freshwater was provided ad libitum. Results showed that while all the control does were observed to stand to be mounted and mated, none of the infected does did. Also, the pattern of the mean percentage vaginal exfoliated cell types encountered between the control and infected doe groups were converse. While parasabal cells changed from $2.90 \pm 0.03 \%$ during proestrus through $3.05 \pm 0.46 \%$ during estrus to $2.42 \pm 0.08 \%$ at diestrus in the control does, it changed from $22.07 \pm 0.56 \%$ during expected proestrus through $8.48 \pm 0.05 \%$ during expected estrus to $28.05 \pm 1.09 \%$ respectively in the infected does. In like manner, intermediate cell changed from $11.10 \pm 0.03 \%$ during proestrus through $11.10 \pm 0.31 \%$ during estrus to $1.21 \pm 1.00 \%$ during diestrus in control does while it changed from $27.27 \pm 0.08 \%$ during expected proestrus through $42.37 \pm 2.39 \%$ during expected estrus to $40.24 \pm 1.06 \%$ during expected diestrus in infected does. Similarly, superficial cells changed from $56.25 \pm 0.75 \%$ during proestrus through $63.70 \pm 1.05 \%$ during estrus to $7.37 \pm 0.01 \%$ during diestrus while it changed from $0.00 \%$ during expected proestrus through $3.39 \pm 0.02 \%$ during expected estrus to $63.70 \pm 1.05 \%$ during estrus to $6.10 \pm 0.01 \%$ during expected diestrus. In the control does, the mean percentage neutrophils changed from $29.75 \pm 0.04 \%$ during proestrus through $22.14 \pm 0.65 \%$ during estrus to $86.70 \pm 1.68$ during diestrus while in the infected does, it changed from $50.64 \pm 0.68 \%$ during expected proestrus through $45.76 \pm 6.05 \%$ during expected estrus to $25.61 \pm 2.85 \%$ during expected diestrus. The findings in the infected group of does suggest an arrest of the physiological processes leading to the exhibition of "heat" and contradict the observation in the control does. It is concluded that Trypanosoma brucei infection in the WAD does is the cause of anoestrous observed in this study.

KEY WORDS: Receptivity to mating; Vaginal exfoliates; Trypanosoma brucei; WAD does; Estrumate®.

\section{INTRODUCTION}

The devastating effects of trypanosome infection on the health and productivity of people and livestock in tropical Africa has been well documented (Gasser, 1963; Apted, 1970; Sekoni, 1994). Reproductive symptoms that have been associated with trypanosomosis in the females of most species include irregular oestrus, infertility, sterility, abortion, still birth and neonatal death (Ikede, 1979; Faye et al., 2004).
The cytology of vaginal exfoliates have been described in the goat (Pretorius, 1997; Perez-Martinez et al., 1999). Its application in the detection of 'heat' and perhaps, the optimum breeding time in both natural mating as well as artificial insemination purposes in the WAD goat had also been reported (Ola et al., 2006; Leigh \& Ajibade, 2010). There is a paucity of information on the possibility 
of association of any reported reproductive disorder in animal trypanosomiasis with exfoliated vaginal cell pattern. The WAD goats are found in areas endemic/enzootic with Trypanosomiasis. This study was therefore designed to investigate the success of estrus monitored by willingness to accept the male (i.e. buck) and vaginal exfoliate pattern in Trypanosoma brucei infected female WAD goats synchronized with Estrumate ${ }$.

\section{MATERIAL AND METHOD}

Animals and Management. Twenty-one adult WAD goats consisting of 3 bucks and 18 does were involved in the study. The goats were kept in the small ruminant Unit of the Department of Veterinary Surgery and Reproduction, University of Ibadan. The three bucks were kept in a single pen while the does were randomly divided into two groups (i.e. Group A and B). Group A consisted of 10 does which served as control while Group B consisted of 8 does which served as test group. Each group was kept together in a pen and each doe wore a neck tag labeled between AG13 and AG30. The goats were fed with elephant grass in the mornings and commercial feedstuff containing $15.23 \% \mathrm{CP}$ at the rate of $0.25 \mathrm{~kg} / \mathrm{head}$ in the afternoons. Freshwater was provided in their pens ad libitum. The goats were not allowed to graze the paddock throughout the study.

Source of Trypanosoma brucei. Trypanosoma brucei was obtained from passaged rats from the Department of Veterinary pathology, University of Ibadan. The strain was originally obtained from the Nigerian Institute for Trypanosomasis Research (NITR), Vom, Plateau State, Nigeria.

Parasite Estimation in albino rats and inoculation. Parasitaemia in albino rats was evaluated at $8.4 \times 107$ Trypanosomes per milliliter by haemocytometrical method using blood obtained from the tail vein. Further dilution of the blood was made with normal saline to obtain an inoculation dose of $4.8 \times 105$ trypanosomes $/ 0.5 \mathrm{ml}$.

Oestrous synchronization. All animals used in the study were synchronized using the method described by Leigh $e t$ al. (2010). Briefly, this involved the administration of a double injection, seven days apart of Estrumate ${ }^{\circledR}$ (Scherring-Plough Animal Health Corp; Germany) to each doe. Both Groups A (i.e. control) and B (i.e. test group) does received $125 \mathrm{mcg}$ of Estrumate ${ }^{\circledR}$ (i.e. chloprostenol sodium) via intramuscular route. The administration of the first dose of Estrumate ${ }^{\circledR}$ was done on day 12 after parasite inoculation.
Re-synchronization of oestrus. In both groups A and B, the does which failed to show estrus as detected by not standing to be mated were re-synchronized 18 days after the last intramuscular administration of Estrumate ${ }^{\circledR}$. They were then closely observed for signs of estrus as before.

Receptivity to mating activity. The does in group A and B were brought into the pen of the bucks for observation of their response to mating activity. This procedure was carried out thrice daily (i.e. 0800hours, 1200 hours and 1600 hours) starting from the 72nd hour following 2 nd injection of Estrumate ${ }^{\circledR}$. Observation was recorded on whether the does stood to be mated or butted the buck.

Collection of vaginal smear and cytology. Vaginal smear was collected from the does with the aid of improvised vaginal swabs which consisted of clean, soft and gentle, highly absorbent pure cotton buds from Thailand. The vulva and perineum were rinsed with clean water and gently wiped with a clean towel. Each doe was well restrained in standing position by an assistant and the swab was gently inserted into the anterior vaginal with the right hand while the left thumb and fore-finger were used to expose the vulva lips. Hands were gloved. At the anterior vagina, the swab was gently and briskly rolled against the vaginal mucosa and carefully withdrawn. The swab was immediately smeared on a warm gland slide and stained with Giemsa. This process was performed daily between 0800 hours and 0900hours. The cells encountered in the vaginal smear were categorized as percentage of matured (i.e. superficial), immature (parabasal and intermediate) and leucocytes. Twenty five cells were counted from four fields of each slide and the percentage of each cell type was recorded.

Data analysis. Data collected in the mating receptivity experiment was recorded as "Accepted mating" or "Declined mating" while that on vaginal cytology was summarized as mean percentages of exfoliated cells and subjected at every stage of the cycle to Student -t- statistic (Elston \& Johnson, 2008) with $<=5 \%$.

\section{RESULTS}

Receptivity to mating activity. Table I below shows the variation in the mating responses of does in groups ' $\mathrm{A}$ ' and 'B' to bucks in the experiment. Figure 5.1 also shows some portion of the ejaculate hanging from the vulva of one of the control does immediately after the male dismounted. Following the synchronization protocol involving the administration of $125 \mathrm{mcg}$ of Estrumate ${ }^{\circledR}$, the does in both groups were introduced to the bucks for mating activity. 
Table I. Variation in the mating responses of groups A and B does to different dosages of Estrumate ${ }^{\circledR}$ during the study.

\begin{tabular}{|c|c|c|c|c|c|}
\hline & $\begin{array}{l}\text { Total } \\
\text { no f f } \\
\text { does }\end{array}$ & $\begin{array}{l}\text { no f does mounted and } \\
\text { mated during } 72-96 \text { hours } \\
\text { after } 2^{\text {nd }} \text { intramuscular } \\
\text { injection of } 125 \mathrm{mcg} \\
\text { Estrumate }^{\circledR}\end{array}$ & $\begin{array}{l}\text { n of does mounted and mated } \\
\text { during 192-216 th hours } \\
\text { following administration of } \\
125 \mathrm{mcg} \text { Estrumate }\end{array}$ & $\begin{array}{l}\text { n of does mounted and } \\
\text { mated during } 72-96^{\text {th }} \\
\text { hours following single } \\
\text { administration of } \\
250 \text { mcg Estrumate }\end{array}$ & $\begin{array}{l}\text { Total n of does } \\
\text { that responded to } \\
\text { treatment with } \\
\text { Estrumate }^{\circledR}\end{array}$ \\
\hline Group 'A' & 10 & 7 & 2 & 1 & 10 \\
\hline Group 'B' & 8 & 0 & 0 & 0 & 0 \\
\hline
\end{tabular}

Table II. Mean \% of cellular exfoliates encountered in groups 'A' and 'B' does during the study. The various mean percentage differences between groups 'A' and 'B' does during each stage of the study as shown in Table 5.II above were significant $(\mathrm{P}<0.05)$.

\begin{tabular}{lcccc}
\hline & $\begin{array}{c}\text { Parabasal cells (Mean } \\
\pm \text { S.D) } \%\end{array}$ & $\begin{array}{c}\text { Intermediate cells } \\
(\text { Mean } \pm \text { S.D) } \%\end{array}$ & $\begin{array}{c}\text { Superficial cells } \\
\text { (Mean } \pm \text { S.D) } \%\end{array}$ & $\begin{array}{c}\text { Neutrophils } \\
(\text { Mean } \pm \text { S.D) } \%\end{array}$ \\
\hline Proestrus (group A) & $2.90 \pm 0.03$ & $11.10 \pm 0.03$ & $56.25 \pm 0.75$ & $29.75 \pm 0.04$ \\
Expected proestrus (group B) & $22.07 \pm 0.56$ & $27.27 \pm 0.08$ & 0.00 & $50.64 \pm 1.68$ \\
Estrus (group A) & $3.05 \pm 0.46$ & $11.10 \pm 0.31$ & $63.7 \pm 1.05$ & $22.14 \pm 0.65$ \\
Expected Estrus (group B) & $8.48 \pm 0.05$ & $4237 \pm 2.39$ & $3.39 \pm 0.02$ & $4576 \pm 6.05$ \\
Diestrus (group A) & $2.42 \pm 0.08$ & $1.21 \pm 1.00$ & $7.37 \pm 0.01$ & $86.70 \pm 1.68$ \\
Expected diestrus (group B) & $28.05 \pm 1.09$ & $40.24 \pm 1.06$ & $6.10 \pm 0.01$ & $25.61 \pm 2.85$ \\
\hline
\end{tabular}

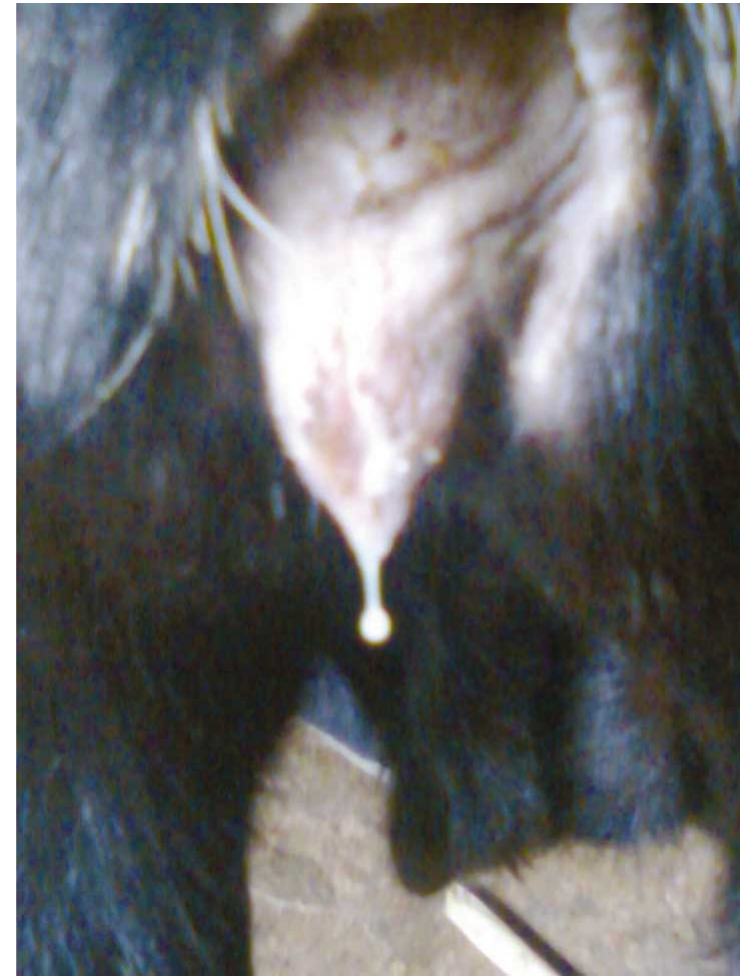

Fig. 1. Showing the perineal region of one of the control (group A) does with semen hanging from the vulva just after mating.

Seven (7) out of the 10 does in group 'A' accepted to be mated by the bucks between 72 and 96 hours following the 2nd intramuscular injection of Estrumate, ${ }^{\circledR}$ while 2 of the does accepted mating only between 192 and 216th hours after 2nd injection with Estrumate $\circledR$. Throughout this period, one doe (AG 24) did not accept mating. AG 24 was later

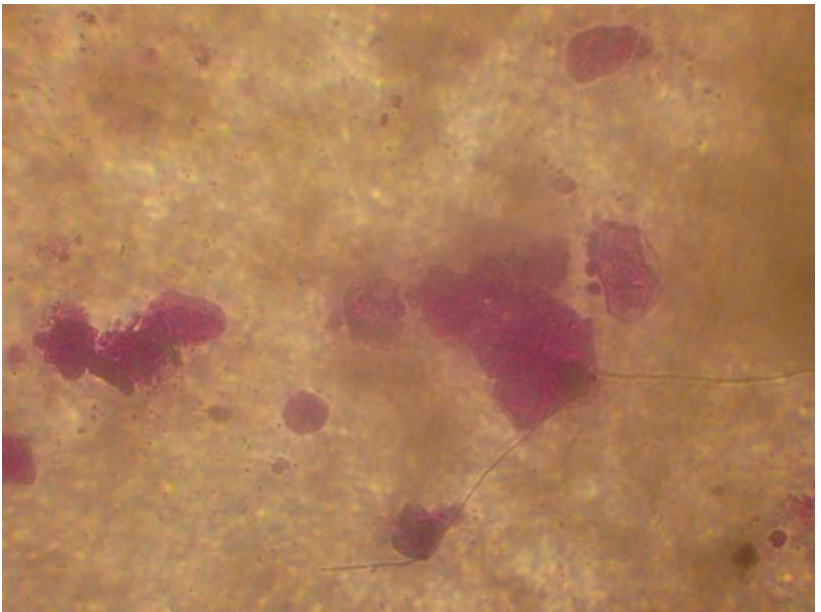

Fig. 2. Cytology of proestrus in control does showing deep staining parabasal cell.

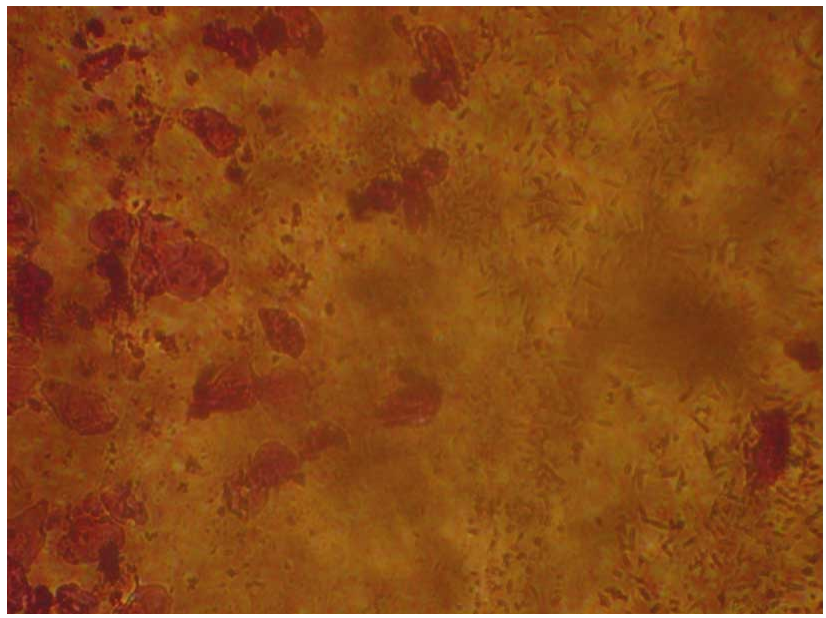

Fig. 3. Cytology of estrus in control does showing superficial cells along with numerous sperm cells. 
administered with a single injection of $250 \mathrm{mcg}$ Estrumate ${ }^{\circledR}$ on day 18 after completing the initial protocol of synchronization. Following re-introduction to the bucks between 72-96th hour after this treatment, AG 24 was observed to stand to be mounted and mated. None of the eight (8) does in group 'B' however was observed to stand to be mounted nor mated following introduction to the bucks starting from the 72nd hour through 216th hour after the second intramuscular injection of $125 \mathrm{mcg}$ Estrumate ${ }^{\circledR}$. Following their treatment with a single intramuscular injection of $250 \mathrm{mcg}$ Estrumate $\AA$, they were also not observed to stand to be mounted or mated.

Vaginal cytology. Figures 2 to 7 below shows the pattern of exfoliated vaginal cells in both groups 'A' and 'B' does during the experiment. Figures 2, 3 and 4 are for group 'A' does while figure 5, 6 and 7 are for group ' $\mathrm{B}$ ' does. The figures $\mathrm{d}$ show differences in quantity and type of the different cells

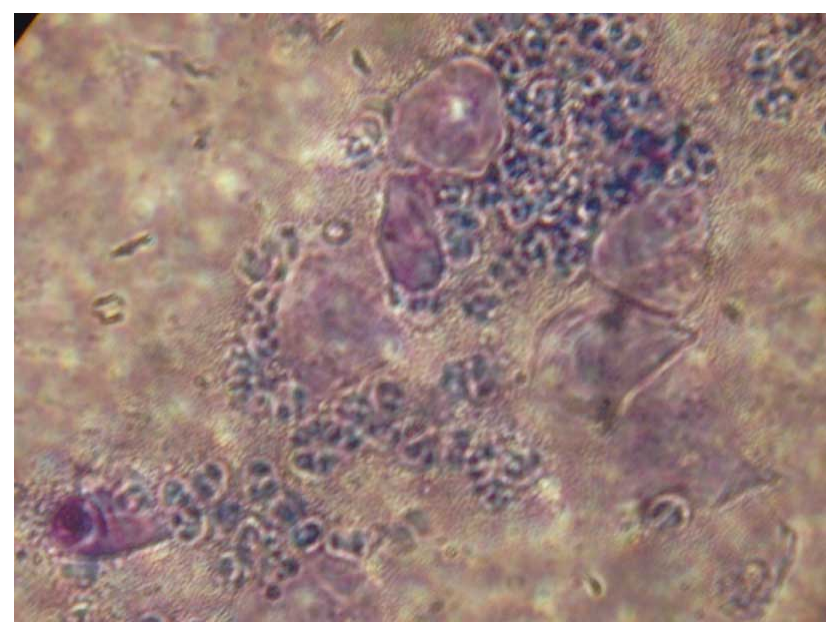

Fig. 4. Cytology of diestrus in control does showing numerous neutrophils, few superficial cells and few other immature epithelial cells.

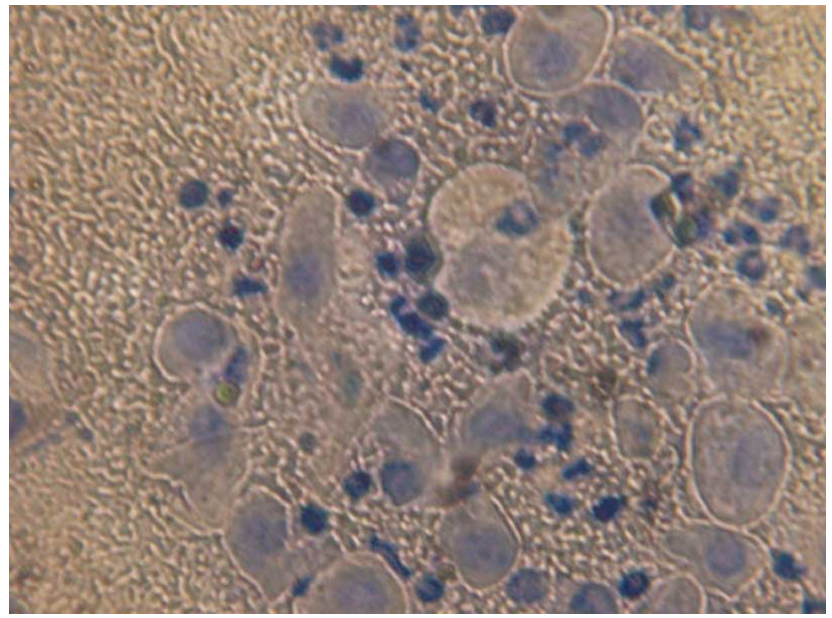

Fig. 5. Cytology of expected proestrus in infected does showing abundance of parabasal and intermediate cells and numerous neutrophils. in the vaginal smear as the does pass through the different stages of the oestrous cycle in response to injection with Estrumate ${ }^{\circledR}$. One of the does (i.e. AG 16) in the control group was however confirmed to be mated for a second time, six (6) days after an initial mating exercise as evidenced by the presence of sperm cells in its vaginal smear. As shown in Table II below, for group 'A' does, the mean percentages of each cell type during proestrus are $2.90 \pm 0.03 \%$ (parabasal), $11.10 \pm 0.03 \%$ (intermediate), $56.25 \pm 0.75$ (superficial) and $29.75 \pm 0.04 \%$ (neutrophils). During estrus, $3.05 \pm 0.46 \%$ (parabasal), $11.10 \pm 0.31 \%$ (intermediate), $63.7 \pm 1.05 \%$ (superficial) and $22.14 \pm 0.65) \%$ neutrophils. The estrus period was further shown (figure 3 ) $\%$ by presence of sperm cells in the vaginal smear in the study. In the immediate diestrus following at the end of mating activity, the cells chiefly observed included parabasal $(2.42 \pm 0.08) \%$ intermediate $(1.21 \pm 1.00) \%$, superficial $(7.37 \pm 0.01) \%$ and neutrophils $(86.7 \pm 1.68) \%$.

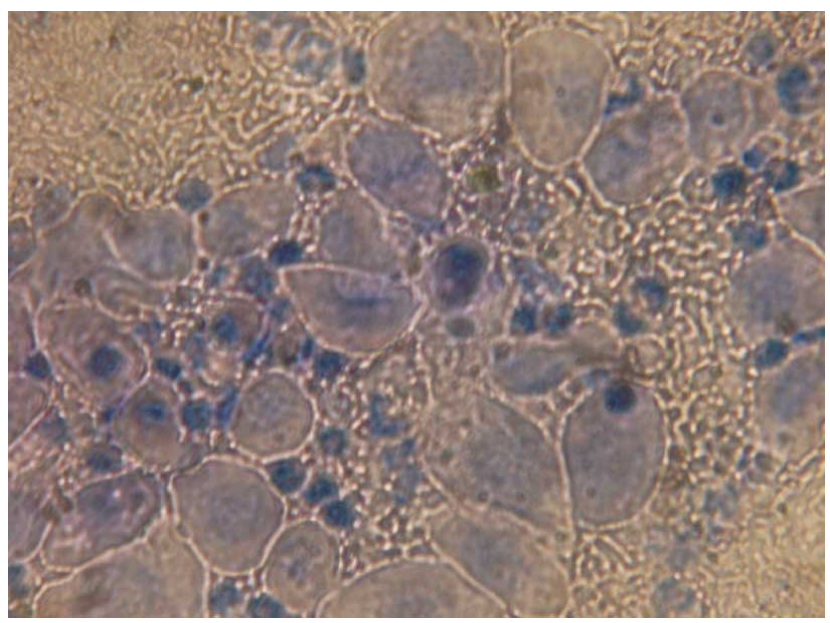

Fig. 6. Cytology of expected estrus in infected does showing more of intermediate cells than parabasal cells and numerous neutrophils.

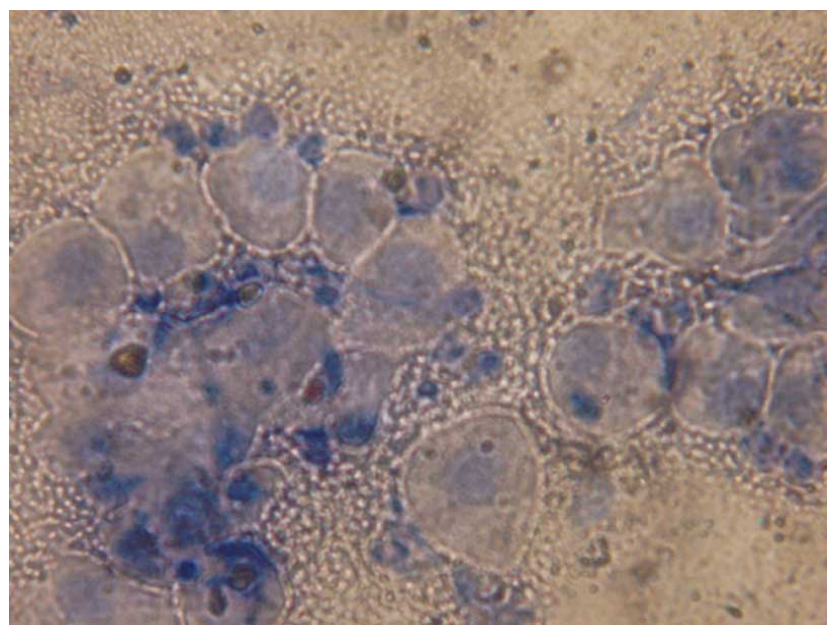

Fig. 7. Cytology of expected diestrus in infected does showing abundance of parabasal and intermediate cells and numerous neutrophils. 
For the eight (8) WAD does in group 'B', none of their vaginal smears was positive for sperm cells throughout the study. During the expected proestrus i.e. 48-72 hours post intramuscular administration of either $125 \mathrm{mcg}$ or $250 \mathrm{mcg}$, Estrumate ${ }^{\circledR}$ the mean percentages of exfoliated cells were as follows: parabasal $(22.07 \pm 0.56) \%$, intermediate $(27.27 \pm 0.08) \%$, superficial $(0) \%$ and neutrophils $(50.64 \pm 1.68) \%$. During the expected estrus i.e. 72-96 hours, the mean percentages of the cells were parabasal $(8.48 \pm 0.05) \%$, intermediate $(42.37 \pm 2.39) \%$, superficial $(3.39 \pm 0.02) \%$ and neutrophils $(45.76 \pm 6.05) \%$. During the expected diestrus, the mean percentages of the vaginal cells were: Parabasal $(28.05 \pm 1.09) \%$, intermediate $(40.24 \pm 1.06) \%$, superficial $(6.10 \pm 0.01) \%$ and neutrophils $(25.61 \pm 2.85) \%$. The differences between the mean percentage values for each stage of the study between control and infected does were significant $(\mathrm{P}<0.05)$.

\section{DISCUSSION}

The result of the present study on acceptance of mounting and mating by the does in both groups ' $\mathrm{A}$ ' and ' $\mathrm{B}$ ' showed that all does in group 'A' i.e. control, were brought into standing estrus by the intramuscular injection of Estrumate ${ }^{\circledR}$. During 72-96 hours following the initial administration of $125 \mathrm{mcg}$ Estrumate $\AA$, $70 \%$ of the control does responded positively to mating. This observation is similar to our earlier report (Leigh et al.). It is also interesting that the present result again attests to the reliability of the estrus synchronization protocol whereby two injections of a luteolytic agent (PGF2?) was administered 7 days apart to WAD does as described by Leigh et al. The administration of exogenous luteolytic agent during the mid-luteal phase results in premature luteolysis leading to a fall in peripheral progesterone concentration and an increase in gonadotropin and oestradiol -17 beta secretion in farm animals (Ball \& Peters, 2004). These hormonal changes gradually culminate in ovulation in intact animals (Noakes et al., 2001). It is possible that the rate at which these processes occur differ in different individual animals or that they are affected by the availability of certain chemical. This explanation may stand for the observation in the study where two of the control does where receptive to the bucks during 192-216th hours following the second injection of $125 \mathrm{mcg}$ Estrumate ${ }^{\circledR}$. The single doe which failed to come into estrus with two injections of $125 \mathrm{mcg}$ but responded positively to $250 \mathrm{mcg}$ Estrumate ${ }^{\circledR}$ suggests that indeed, ovarian threshold to luteolytic agents differ with different animals. While some respond to moderate/normal doses, others require higher doses to attain adequate blood level of the chemical substance needed for luteolysis (Greyling \& van der Nest, 2000). In the case of group 'B' does i.e. infected group none of the does showed positive response to estrus as evaluated by standing to be mounted and or mated during the course of the study. This finding suggests that the infection prevented the does from exhibiting estrus in response to the administration of Estrumate ${ }^{\circledR}$ at both $125 \mathrm{mcg}$ and $250 \mathrm{mcg}$ dose per animal. Similar observations of anoestrus as the present one have been reported earlier (Elhassan et al., 1994; Sekoni). The present finding may suggests a possibility of affection of the normal physiological processes leading to behavioural and possibly fertile estrus in the female animal. Such affection may have occurred at the level of the hypothalamic regulation of anterior pituitary hormones through the production of gonadotropin releasing hormone $(\mathrm{GnRH})$ or at the level of the anterior pituitary through the elaboration of follicle stimulating hormone (FSH) and luteinizing hormone $(\mathrm{LH})$ or at the level of the ovary through the production of estrogens from growing follicles (Gordon, 2005). Some workers have reported acute coagulative necrosis of adenohypophysis in $T$. brucei infected sheep (Mutayoba et al., 1995) while others have observed a failure of the hypothalamic - pituitary -adrenal axis in response to insulin induced hypoglycaemia in Boran cattle experimentally infected with Trypanosoma congolense (Abebe et al., 1993). Others have equally reported hypogonadism associated with Rhodesian sleeping sickness (Petzke et al., 1996).

The result of the study on vaginal exfoliates subsequent to the administration of Estrumate ${ }^{\circledR}$ have been presented in Table II as well as figures 2 to 7 . The pattern of the nature of the vaginal cells encountered during each oestrual phase of the study in both control and infected does are quite informative. For instance, in the control does the mean percentage parabasal cells increases slightly from $2.90 \pm 0.03 \%$ during proestrus to $3.05 \pm 0.46 \%$ at estrus and then declined to $2.42 \pm 0.08 \%$ during diestrus. On the other hand, in the infected does, the mean percentage parabasal cells declined from $22.07 \pm 0.56 \%$ at the expected proestrus to $8.48 \pm 0.05$ during expected estrus but again rose to 28.05 \pm 1.09 during expected diestrus. Similarly, the intermediate cells for the control does decreased from $11.10 \pm 0.03 \%$ during proestrus to $1.21 \pm 1.00 \%$ during diestrus while for the infected does, it increased from expected proestrus value of $27.27 \pm 0.08 \%$ to $40.24 \pm 1.06 \%$. The decrease observed in the intermediate cells in the control does must have given rise to the appreciable value of $56.25 \pm 0.75 \%$ superficial cells observed during the following proestrus while the increase of intermediate cells in the infected does suggest a redirection of the normal pattern or process of the physiological changes occurring in the does. Hence, during the expected proestrus, no superficial cells were found. By the time of estrus in the control does, superficial cells have increased to 
$63.70 \pm 1.05 \%$ while only $3.39 \pm 1.02 \%$ were found in the infected does. These differences may suggest why the infected does did not progress to estrus in the study. According to Rodgers (1993) and Perez-Martinez et al., the cellular pattern of vaginal exfoliates are consistent with physiological changes in the animal and cell types are usually depictive of the reproductive status in the animal. On this basis, there will be no explanation for groups of does with significant disparity in mean percentages of vaginal cellular exfoliates as in the present study to be in the same phase of oestrual cycle. The observation in the cellular pattern of vaginal exfoliates in this study suggest that there was an arrest in the development and formation of superficial cells in the infected does. Observations with the mean percentage neutrophils are also similar. While in the control does, neutrophil increased from $29.75 \pm 0.04 \%$ during proestrus to
$86.70 \pm 1.8 \%$ at diestrus, it decreased from $50.64 \pm 1.68 \%$ during expected proestrus to $25.61 \pm 2.85$ during the expected diestrus. Increase in neutrophils during diestrus is usually consistent with evidence of mating activity or arrival of diestrus (Subandrio \& Noakes, 1992; Faundez et al., 1994; Ahmadi \& Nazifi, 2006). This finding further confirmed earlier observation that the infected does did not allow mounting or mating during the study. The finding in the present study will be interesting to theriogenologists in the tropics in the sense that the WAD does in the infected group were synchronized only twelve days after parasite inoculation. The observations in this study therefore ascertain the virulence of Trypanosoma brucei in the WAD goat with respect to reproductive pathology. It is concluded that experimental Trypanosoma brucei infection in the WAD does led to failure of estrus following synchronization with Estrumate®.

LEIGH, O. O. \& FAYEMI, O. E. Observaciones sobre el estro monitorizado por la receptividad a la actividad de apareamiento y el patrón de exfoliación vaginal en cabras WAD infectadas por Trypanosoma brucei sincronizadas con Estrumate®. Int. J. Morphol., 29(3):762-768, 2011.

RESUMEN: Los efectos de la infección experimental por Trypanosoma brucei sobre la receptividad a la actividad de apareamiento y el patrón de exfoliación vaginal fueron monitoreados utilizando 21 cabras WAD adultas sincronizadas con doble inyección, a los siete días de diferencia de Estrumate ${ }^{\circledR}$. De las 21 cabras utilizadas eran 3 machos y 18 hembras. Las hembras se dividieron al azar en grupo control "A" con 10 sujetos y un grupo de prueba "B" con 8. Las cabras fueron alimentadas con pasto y alimento comercial que contenía $15,23 \%$ de CP en tasa de $0,25 \mathrm{~kg}$ /por cabeza en las tardes. Agua fresca fue proporcionada ad libitum. Los resultados mostraron que mientras todos las cabras del grupo control pudieron ser montadas y acopladas, ninguna de las infectadas pudo. Además, fue contradictorio el patrón de la media porcentual de los tipos de células vaginales exfoliadas encontradas entre los grupo control e infectadas. Mientras que las células parabasales cambiaron desde un 2,90 $\pm 0,03 \%$ durante el proestro, al 3,05 $\pm 0,46 \%$ durante el estro y $2,42 \pm 0,08 \%$

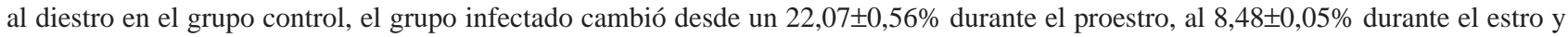
$28,05 \pm 1,09 \%$ al diestro. De la misma forma, las célula intermedias cambiaron de un $11,10 \pm 0,03 \%$ durante el proestro, al $11,10 \pm 0,31 \%$ durante el estro y al 1,21 $\pm 1,00 \%$ durante el diestro en el grupo control, mientras que en el grupo infectado pasó del 27,27 $\pm 0,08 \%$ durante el proestro, al $42,37 \pm 2,39 \%$ durante el estro y al 40,24 $\pm 1,06 \%$ durante el diestro. Las células superficiales pasaron desde un $56,25 \pm 0,75 \%$ durante el proestro, $63,70 \pm 1,05 \%$ durante el estro, hasta un 7,37 $\pm 0,01 \%$ durante el diestro, mientras en el grupo infectado pasaron de un $0.00 \%$ durante el proestro, al 3,39 $\pm 0,02 \%$ durante la espera del estro, luego al 63,70 $\pm 1,05 \%$ durante el estro, hasta un $6,10 \pm 0,01 \%$ durante la espera del diestro. En el grupo control, el porcentaje promedio de los neutrófilos pasó de un 29,75 $\pm 0,04 \%$ durante el proestro,

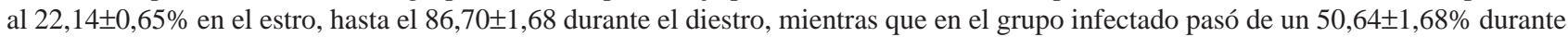
la espera del proestro, a un $45,76 \pm 6,05 \%$ durante la espera del estro, hasta un $25,61 \pm 2,85 \%$ durante la espera del diestro. Los resultados en el grupo de infectado sugieren una detención de los procesos fisiológicos que conducen a la exposición de "calor", en contradicción con lo observado en el grupo control. Se concluye que la infección por Trypanosoma brucei en las cabras WAD es la causa del anestro observado en este estudio.

PALABRAS CLAVE: Receptividad del apareamiento; Exfoliación vaginal; Trypanosoma brucei; Cabras WAD; Estrumate ${ }^{\circledR}$.

\section{REFERENCES}

Abebe, G.; Eley, R. M. \& ole-MoiYoi, O. K. Reduced responsiveness of the hypothalamic-pituitary-adrenal axis in Boran (Bos inducus) cattle infected with Trypanosoma congolense. Acta Endocrinol. (Copenh), 129(1):75-80, 1993.

Ahmadi, M. R. \& Nazifi, S. Evaluation of reproductive sta- tus with cervical and uterine cytology in fat-tailed sheep. Comp. Clin. Pathol., 15(3):161-4, 2006.

Apted, F. Clinical manifestations and diagnosis of sleeping sickness. In: Mulligan, H. W. (Ed.). The African Trypanosomiasis. London, George Allen and Unwin, 1970. pp.614-44. 
LEIGH, O. O. \& FAYEMI, O. E. Observations on estrus as monitored by receptivity to mating activity and pattern of vaginal exfoliates In Trypanosoma brucei - infected WAD goat does synchronized with Estrumate®. Int. J. Morphol., 29(3):762-768, 2011.

Ball, P. J. H \& Peters, A. R. Reproduction in cattle. $3^{\text {rd }}$ Ed. Oxford, Blackwell Publishing, 2004.

Elhassan, E.; Ikede, B. O. \& Adeyemo, O. Trypanosomosis and reproduction: I. Effect of Trypanosoma vivax infection on the oestrous cycle and fertility in the ewe. Trop. Anim. Health Prod., 26(4):213-8, 1994.

Elston, R. C. \& Johnson, W. D. Basic Biostatistics for geneticists and epidemiologists. A Practical Approach. $1^{\text {st }}$ Ed. United Kingdom, John Wiley \& Sons, 2008.

Faye, D.; Sulon, J.; Kane, Y.; Beckers, J. F.; Leak, S.; Kaboret, Y.; de Sousa, N. M.; Losson, B. \& Geerts, S. Effects of an experimental Trypanosoma congolense infection on the reproductive performance of West African Dwarf goats. Theriogenology, 62(8):1438-51, 2004.

Faundez, R.; Duszewska, A. M; Klucinski, W.; Spohr, I. \& Sitarska, E. Occurrence of leukocytes and epithelial cells in the lumen of the reproductive tract during the ovarian cycle. In proceedings of the 18th World Buiatr Congress. Bologna, Italy, 1994. p.308.

Gasser, S. The Bane of Tropical Africa. Lancet 1:1091, 1963.

Gordon, I. R. Reproductive Technologies in Farm Animals. Wallingford, CABI, 2005. pp.147-53.

Greyling, J. P. \& van der Nest, M. Synchronization of oestrus in goats: dose effect of progestagen. Small Rumin. Res., 36(2):201-7, 2000.

Ikede, B. O. Genital lesions in experimental chronic Trypanosoma brucei infection in rams. Res. Vet. Sci., 26(2):145-51, 1979.

Leigh, O. O. \& Ajibade, Z. O. Conception Following Transcervical Insemination with Predetermined Ejaculate Concentration in Synchronized West African Dwarf Does. Global Veterinary, 5(4):239-42, 2010.

Leigh, O. O; Raheem, A. K. \& Oluwadamilare, J. A. O. Improving the Reproductive Efficiency of the Goat: Vaginal Cytology and Vulvas Biometry as Predictors of Synchronized Estrus/Breeding Time in West African Dwarf Goat. Int. J. Morphol., 28(8):923-8, 2010.

Mutayoba, B. M.; Eckersall, P. D.; Seely, C.; Gray, C. E.; Cestnik, V.; Jeffcoate, I. A. \& Holmes, P. H. Effects of Trypanosoma congolense on pituitary and adrenocortical function in sheep: responses to exogenous corticotrophin-releasing hormone. Res. Vet. Sci., 58(2):180-5, 1995.

Noakes, D. E.; Parkinson, T. J. \& England, G. C. W. Arthur"s Veterinary reproduction and obstetrics. $8^{\text {th }}$ Ed. Edinburg, Saunders, 2001. pp.46-51.

Ola, S. I.; Sanni, W. A. \& Egbunike, G. Exfoliative vaginal cytology during the oestrous cycle of West African dwarf goats. Reprod. Nutr. Dev., 46(1):87-95, 2006.

Perez-Martinez, M.; Mendoza, M. E. \& Romano, M. C. Exfoliative vaginal cytology and plasma levels of estrone and estradiol-17b in young and adult goats. Small Rum. Res., 33(2):153-8, 1999.

Petzke, F.; Heppner, C.; Mbulamberi, D.; Winkelmann, W.; Chrousos, G. P.; Allolio, B. \& Reincke, M. Hypogonadism in Rhodesian sleeping sickness: evidence for acute and chronic dysfunction of the hypothalamicpituitary-gonadal axis. Fertil. Steril., 65(1):68-75, 1996.

Pretorius, P. S. Vaginal cytological changes in the cycling and anoestrous Angora goat doe. J. S. Afr. Vet. Assoc., 48(3):169-71, 1977.

Rodgers, K. S. The canine estrus cysle: staging using vaginal cytology. Compend. Contin. Educ. Pract. Vet., 19:103644, 1993.

Sekoni, V. O. Reproductive disorders caused by animal trypanosomiases: a review. Theriogenology, 42(4):557$70,1994$.

Subandrio, A. L \& Noakes, D. E. The influence of the stage of the bovine oestrous cycle on the chemotactic stimulus of oyster glycogen to intrauterine neutrophils. Br. Vet. J. 148(2):163-5, 1992.

\section{Correspondence to: \\ Dr. O. O Leigh \\ Department of Veterinary Surgery and \\ Reproduction, University of Ibadan. \\ NIGERIA}

Phone: 08033266825

Email: damilareolufisayo@yahoo.com

Received: 30-03-2011

Accepted: 13-05-2011 